\title{
Voltammetric characteristics of miconazole and its cathodic stripping voltammetric determination
}

\author{
FRANCISCO C. PEREIRA, NELSON R. STRADIOTTO and MARIA VALNICE B. ZANONI
}

Instituto de Química, Universidade Estadual Paulista, Cx. Postal 355, 14801-970 Araraquara, SP, Brazil

Manuscript received on July 13, 2001; accepted for publication on February 26, 2002;

presented by FERNANDO GALEMBECK

\begin{abstract}
Miconazole is reduced at mercury electrode above $\mathrm{pH} 6$ involving organometallic compound formation, responsible for an anomalous polarographic behavior. The electrodic process presents a large contribution of the adsorption effects. The drug can be determined by cathodic stripping voltammetry from $8.0 \times 10^{-8}$ to $1,5 \times 10^{-6} \mathrm{~mol} \mathrm{~L}^{-1}$ in Britton-Robinson buffer $\mathrm{pH} 8.0$, when pre-accumulated for $30 \mathrm{~s}$ at an accumulation potential of $0 \mathrm{~V}$. A relative standard deviation of $3.8 \%$ was obtained for ten measurements of $1.0 \times 10^{-7} \mathrm{~mol} \mathrm{~L}^{-1}$ miconazole in B-R buffer $\mathrm{pH} 8.0$ and a limit detection of $1,7 \times 10^{-8} \mathrm{~mol} \mathrm{~L}^{-1}$ was determined using $60 \mathrm{~s}$ of deposition time and scan rate of $100 \mathrm{mV} \mathrm{s}^{-1}$. The proposed method is simple, precise and it was applied successfully for the determination of the miconazole in pure form and in commercial formulations, showing mean recoveries of $99.7-98.4 \%$.
\end{abstract}

Key words: miconazole, voltammetry, electroanalysis, determination.

\section{INTRODUCTION}

Miconazole, 1-[2-(2,4-diclorofenil)-2-(2,4-diclorofenil)metoxietil-1H-imidazol, is an imidazole antifungal agent and antibacterial drug (Bennett 1996, Hoogeheide and Wycka 1982). The drug is administered locally or intravenously in cases of local or systemic mycotic infections. As a well established and useful drug it has generated significant analytical interest, several methods have been described for its determination in pharmaceutical formulations or biological fluids. The main methods employed are based on spectrophotometry (Cavrini et al. 1981, Goger and Gokcen 1999, Bonazzi et al. 1998, Kashaba et al. 2000, Erk and Altun 2001) and chromatography (Kobylinka et al. 1996, Indrayanto et al. 1999, Pietra et al.1996, Pietra et al. 1992,

Correspondence to: Maria Valnice Boldrin Zanoni E-mail: boldrinv@iq.unesp.br
Cavrini et al. 1982). While all of these methods proved to be useful for certain studies, most of them are associated with specific procedures, requiring many steps and solvent extractions, lack of specificity and low molar extinction coefficient.

Electrochemical methods have shown remarkable advantage in analysis of drugs in pharmaceutical formulation (Smyth and Vos 1992). On the other hand, the voltammetric reduction of halogenated compounds is well known in the literature (Baizer and Lund 1985). However, only one study found in the literature has investigated the interaction of miconazole with some trace-elements (Willems et al. 1981) by means of polarographyc measurements. The stabilities constants with $\mathrm{Mn}, \mathrm{Fe}, \mathrm{Co}, \mathrm{Ni}$ and $\mathrm{Zn}$ cations have been determined using the shiftting of $E_{1 / 2}$ (half-wave potential) produced in the metal reduction wave in the presence of miconazole. But, 
no work has been reported in the literature dealing with polarographic reduction of miconazole as well adsorptive stripping voltammetric determination of the drug.

The present work describes the electrochemical behavior of miconazole at mercury electrode in order to obtain an adsorptive stripping voltammetric method for determining the drug in aqueous solution and pharmaceutical formulations.

\section{MATERIALS AND METHODS}

Apparatus: Voltammetric experiments were performed with a Metrohm Polarecord E 506 linked to a compatible microcomputer, through a Microquimica interface. The multimode electrode Metrohm stand 663 VA was used in both the hanging mercury electrode (HMDE) and dropping mercury electrode (DME). The three electrode system was completed means of an $\mathrm{Ag} / \mathrm{AgCl}\left(3 \mathrm{~mol} \mathrm{~L}^{-1} \mathrm{KCl}\right)$ reference electrode and a glassy carbon auxiliary electrode.

Reagents: Suprapur grade reagents supplied by Merck and desmineralized water from a Milli-Q system (Milli-pore) were used in the preparation of all solutions. Britton-Robinson (B-R) buffer used as supporting electrolyte was prepared by mixing appropriate amounts of $0.2 \mathrm{~mol} \mathrm{~L}^{-1}$ sodium hydroxide to orthophosphoric acid, acetic acid and boric acid (0.04 $\mathrm{mol} \mathrm{L}^{-1}$ in each) solution.

Procedure: Miconazole stock solution $\left(1.0 \times 10^{-2}\right.$ or $1.0 \times 10^{-4} \mathrm{~mol} \mathrm{~L}^{-1}$ ) were prepared from the dried and pure substance (kindly supplied by Bayer S.A.) by dissolution in methanol. An aliquot of the miconazole standard solution to be investigated was added by micropipette to $20 \mathrm{~mL}$ of deaerated $\mathrm{B}-\mathrm{R}$ buffer at the appropriate $\mathrm{pH}$. The differential pulse mode was used with a pulse amplitude of $50 \mathrm{mV}$, a drop time of $0.8 \mathrm{~s}$, unless stated otherwise. The cathodic stripping voltammograms were obtained using a step of accumulation at $-0.2 \mathrm{~V}$ for $30 \mathrm{~s}$ by stirring unless otherwise stated. Following $15 \mathrm{~s}$ after stopping the stirring, a cathodic voltammogram was recorded, with a $100 \mathrm{mV} \mathrm{s}^{-1}$ scan rate in the linear scan mode.
Analysis of dosage forms by voltammetric method were carried out using a commercial spray of Vodol (nominally $10 \mathrm{mg}$ in miconazole nitrate). An aliquot of this formulation after evaporation of the organic solvent under a stream of nitrogen was diluted with $10 \mathrm{~mL}$ of methanol. Aliquots of $20 \mu \mathrm{L}$ of this solution was transferred directly into the voltammetric cell containing $20 \mathrm{~mL}$ of phosphate buffer $\mathrm{pH}$ 8.0 and the voltammetric curve recorded as above procedure. For tablets, commercial samples of Daktarin were prepared in a simple way. A weighed quantity of the powder equivalent to $10 \mathrm{mg}$ of the studied drug was dissolved into $10 \mathrm{~mL}$ of methanol and aliquots of $20 \mu \mathrm{L}$ of this stock solution was directly added to the voltammetric cell before electrochemical measurements.

Analysis of dosage forms by spectrophotometric method were carried out after complexation of miconazole with bromocresol green dye, following the procedure proposed in the literature by (Cavrini et al. 1981).

\section{RESULTS AND DISCUSSION}

\section{Differential Pulse Polarography}

Miconazole contains electroreducible carbon-chloride bonds that provide the basis for its voltammetric determination. In hydroalcoholic solution; $0.04 \mathrm{~mol} \mathrm{~L}^{-1}$ Britton-Robinson buffer/methanol (1:1), miconazole is readily reduced in the $\mathrm{pH}$ range 8.0-12.0, as is shown in Fig. 1. The cathodic peak located at relatively high negative electrode potential ( $\mathrm{pH}=8.0)$, Fig. 1, Curve B) shifts towards more negative values increasing the $\mathrm{pH}$ values up to $-1.40 \mathrm{~V}$ at $\mathrm{pH} 12.0$. The height of the peak decreases continuously above $\mathrm{pH} 8$, being only about one-third of its original height at $\mathrm{pH}$ 12.0. Analyses of the shapes of the differential-pulse peaks have shown peak half-width values of about $91 \mathrm{mV}$, suggesting a reduction process involving one electron transfer (Bond 1980).

A linear dependence between $\log i_{p}$ versus $\log$ $\mathrm{t}$ was found for differential pulse polarograms obtained from 0.4 to $2.0 \mathrm{~s}$ with a slope of 1.44 , showing 


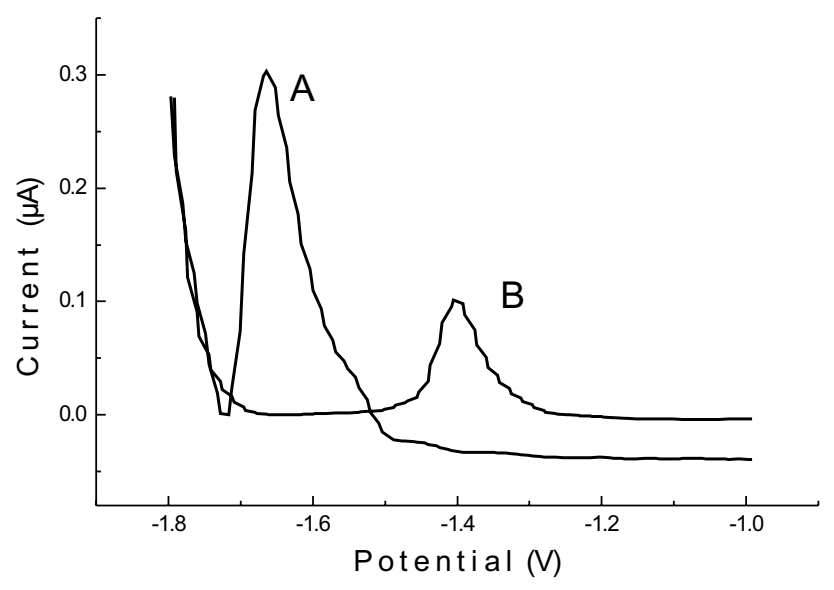

Fig. 1 - Differential pulse polarograms obtained for $5.0 \times 10^{-4} \mathrm{~mol} \mathrm{~L}^{-1}$ of miconazole in pH 8.0 (Curve A) in pH 12.0 (Curve B).

that adsorption is involved in the electrode process (Zuman 1969). The above results were confirmed by means of the calibration curve obtained from $0.05 \mathrm{mM}$ to $0.5 \mathrm{mM}$ of miconazol. The relationship between ip versus concentration has shown a behavior unsuitable as analytical method. Although a linear relationship is obtained the curve does not cross the origin, following the equation: $\operatorname{ip}(\mu \mathrm{A})=$ $-0.655+2465 \mathrm{C}\left(\mathrm{C}=\right.$ concentration $\left.\mathrm{mol} \mathrm{L}^{-1}\right) ; \mathrm{R}=$ $0.992, n=7$. The recorded differential pulse polarographic are also distorted at higher concentrations than $2.0 \times 10^{-4} \mathrm{~mol} \mathrm{~L}^{-1}$, exhibiting anomalous baseline and non-symmetrical polarographic curves, indicating that strong adsorption are present in the electrodic process (Bond 1980).

This behavior is confirmed by cyclic voltammetric investigation. The reduction of $1.0 \times 10^{-3}$ mol L ${ }^{-1}$ of miconazole solution in B-R buffer $\mathrm{pH} 8.0$ shows a cathodic peak at $-1.7 \mathrm{~V}$ and an anodic peak resulting from re-oxidation of the reduction product at reverse potential scan. The difference between the cathodic and the anodic peak potential is almost zero, indicating the occurrence of a reduction process complicated by strong adsorption of reagent and product (Laviron 1974). The influence of scan rate $(v)$ on both peaks height was investigated from $10-500 \mathrm{mV} \mathrm{s}^{-1}$. On plotting ip vs $v$, a linear relationship was observed for both cathodic and anodic peak, which is indicative of an adsorption-controlled process involving the reagent and product generated. Multi cyclic voltammograms repeated at the same mercury drop, do not show any alteration on the height of the cathodic or anodic peak. These results confirm that the generated product on electrode surface is strongly adsorbed on mercury as a stable film, (Laviron 1974).

It is known from the literature, (Pereira et al. 2001, Baizer and Lund 1985), that the formation of organometallic compounds prior or after the electron transfer is often the preferred route of electroreduction of halogenated organic compounds on cathodes of mercury. Therefore, taking into consideration the polarographic results obtained, the overall course of the reduction of miconazole probably follows other imidazole compounds (Pereira et al. 2001, Baizer and Lund 1985), involving a reduction process where an organometallic reaction (eqn 2) could be competing with the reductive cleavage of the halide (eqn 1), as shown in Fig. 6. Hence, the direct participation of mercury on the electrodic pro- 
cess explain all anomalous behavior observed in the polarographic experiments and the reversibility of the cyclic voltammograms in the first or successive scans. However, it is possible to conclude that differential pulse polarography or cyclic voltammetry can not be selected for analytical purposes.

\section{Cathodic Stripping Voltammetry}

The possibility of determining miconazole by stripping voltammetry was considered since the adsorption process detected in the electrochemical reduction could be used as an effective preconcentration step prior to the voltammetric reduction of the drug.

Linear voltammetric studies showed that miconazole is rapidly accumulated on an HMDE from a stirred solution, as shown the linear adsorptive stripping voltammograms obtained for $1.0 \times 10^{-6}$ mol L ${ }^{-1}$ miconazole in B-R buffer $\mathrm{pH} 8.0$ (Fig. 2). The height of the peak was shown to be directly proportional to the scan rate within the range $10-200$ $\mathrm{mV} \mathrm{s}^{-1}$, indicating that the reduction is that of an adsorbed species (Smyth and Vos 1992). On using a scan rate higher than $200 \mathrm{mV} \mathrm{s}^{-1}$ the peak shape was distorted, so a scan rate of $100 \mathrm{mV} \mathrm{s}^{-1}$ was used for further work.

In order to investigate the effect of $\mathrm{pH}$ values on the peak height and peak potential, the stripping voltammetric response was studied for $1.0 \times 10^{-6}$ mol L $\mathrm{L}^{-1}$ in B-R buffer between $7.0-12$. The peak potential is constant at $\mathrm{pH}<8.0$ and shifts linearly towards less negative values at higher $\mathrm{pH}$ values. But, the peak height decreases linearly with $\mathrm{pH}$ increasing as is shown in Fig. 3. So, a value of $\mathrm{pH} 8.0$ was chosen as giving the best results.

The influence of deposition potential on the peak current of $1 \times 10^{-6} \mathrm{~mol} \mathrm{~L}^{-1}$ miconazole was studied by changing potentials between 0 and $-1.2 \mathrm{~V}$. Taking into consideration that higher peak currents are obtained at an accumulation potential of $0 \mathrm{~V}$, this value was chosen as best accumulation potential to pre-concentrate the drug.

The peak current is plotted as a function of accumulation time in Fig. 4. The peak current increases as the deposition time increases up to $60 \mathrm{~s}$, and it is approximately constant after this time, indicating surface coverage.

The influence of miconazole concentration (pure sample) was studied from $8.3 \times 10^{-8}$ to $1.5 \times 10^{-6} \mathrm{~mol} \mathrm{~L}^{-1}$ using accumulation times of $30 \mathrm{~s}$ and $100 \mathrm{~s}$, and the respective curves are shown in Fig. 5. The response was linear in all the range studied for $30 \mathrm{~s}$ of accumulation time, but the curve is linear only up to $4.2 \times 10^{-7} \mathrm{~mol} \mathrm{~L}^{-1}$ when accumulation time of $100 \mathrm{~s}$ was used. An accumulation time of $30 \mathrm{~s}$ are recommended as optimum conditions for the determination of the drug in concentration above $4.2 \times 10^{-7} \mathrm{~mol} \mathrm{~L}^{-1}$.

Repetitive measurements of $1.0 \times 10^{-7} \mathrm{~mol} \mathrm{~L}^{-1}$ miconazole in B-R buffer $\mathrm{pH} 8.0$ using accumulation time and accumulation potential of $30 \mathrm{~s}$ and $0 \mathrm{~V}$ respectively, permitted the evaluation of the precision of the method. The experiment was repeated ten times, the relative standard deviation calculated for $1.0 \times 10^{-7} \mathrm{~mol} \mathrm{~L}^{-1}$ was found to be $3.8 \%$. A detection limit of $1.7 \times 10^{-8} \mathrm{~mol} \mathrm{~L}^{-1}$ was determined using $60 \mathrm{~s}$ of deposition time and scan rate of $100 \mathrm{mV} \mathrm{s}^{-1}$. In order to check the accuracy of the developed method, we carried out a recovery study $(n=3)$ for samples containing $4.2 \times 10^{-7} \mathrm{~mol} \mathrm{~L}^{-1}$, an average recovery of $99 \%$ with a relative standard deviation of $1.6 \%$ was obtained.

The method was applied to some dosage forms containing miconazole nitrate, using the standard method addition. The results obtained for the commercial pharmaceutical formulations as Daktarin (Janssen Pharmaceutical Laboratory) and Vodol (Andromaco Laboratory), following a procedure described in the experimental part, are shown in Table I. The results are in good agreement with the namely in the label of the commercial sample exhibiting recovery of 99.7 and $98.4 \%$ for Daktarin and Vodol, respectively. The coefficient of variation of $1.7 \%$ for DAKTARIN and $1.6 \%$ for VODOL were obtained. The high recovery obtained in the experiment indicates the absence of interference from frequently excipients encountered in this kind of sample. The results (Table II) were compared with that obtained by applying a spectrophotometric method described 


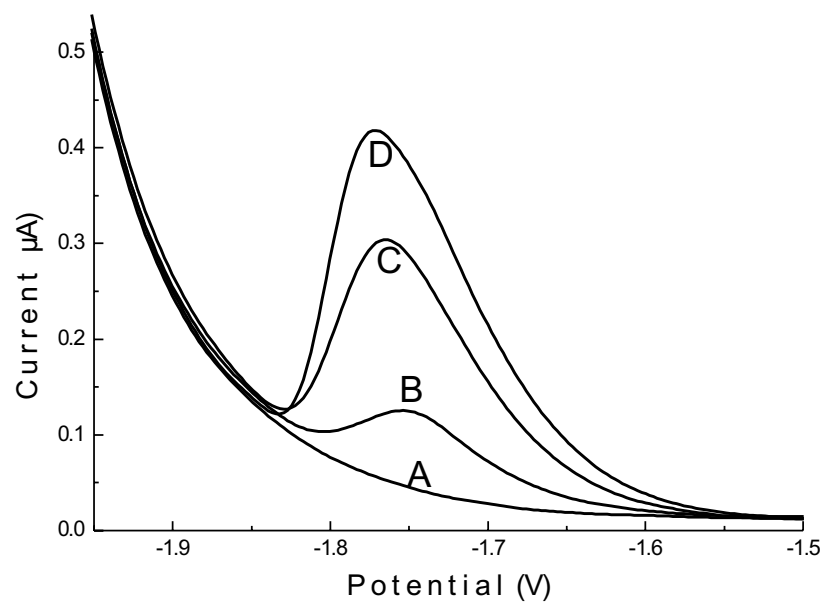

Fig. 2 - Cathodic Stripping voltammograms obtained for $1.0 \times 10^{-6} \mathrm{~mol} \mathrm{~L}^{-1}$ of miconazole in B-R buffer $\mathrm{pH}$ 8.0. Accumulation potential $\left(\mathrm{E}_{\mathrm{ac}}\right)=0 \mathrm{~V}$, Scan rate $=100 \mathrm{mV} \mathrm{s}^{-1}$, using accumulation time $\left(\mathrm{t}_{\mathrm{ac}}\right)$ of: Curve $\mathrm{A}=0 \mathrm{~s}$, curve $\mathrm{B}=15 \mathrm{~s}$, curve $\mathrm{C}=30 \mathrm{~s}$ and curve $\mathrm{D}=60 \mathrm{~s}$.

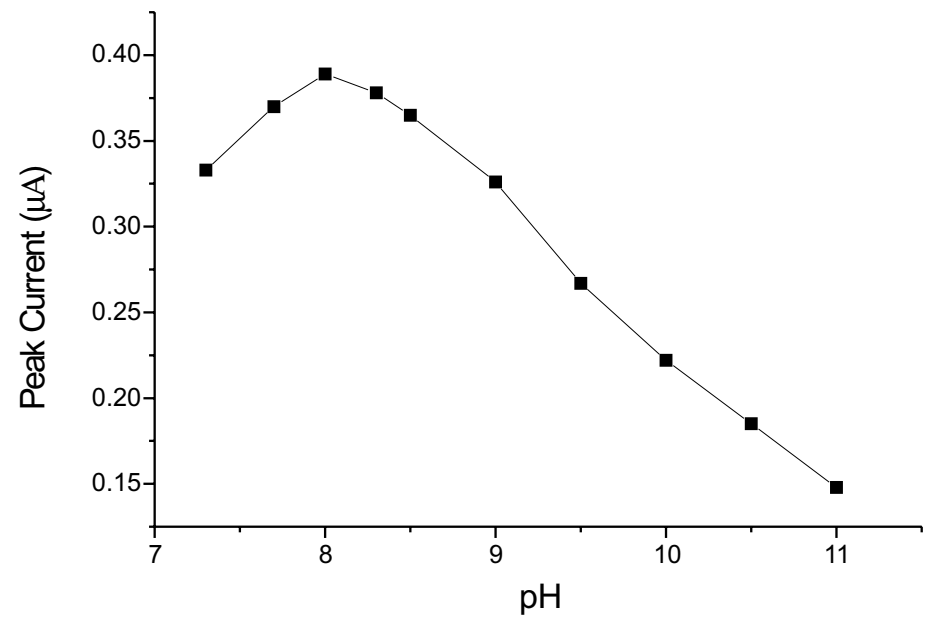

Fig. 3 - Influence of the solution of $\mathrm{pH}$ variation on peak current intensity obtained from cathodic stripping voltammograms of $1.0 \times 10^{-6} \mathrm{~mol} \mathrm{~L}^{-1} \mathrm{mi}-$ conazole. $\mathrm{E}_{\mathrm{ac}}=0 \mathrm{~V}, \mathrm{t}_{\mathrm{ac}}=60 \mathrm{~s}$ and $v=100 \mathrm{mV} \mathrm{s}^{-1}$.

in the literature, (Cavrini et al. 1981). The results obtained for the same commercial sample nominally containing $1 \%$ of miconazole show a mean 100 and $99.0 \%$, showing good agreement between both methods.

The proposed stripping voltammetric method proved to have an adequate precision and accuracy to carry out reliable analysis of miconazole. On the other hand, the voltammetric analysis has presented some advantages when compared with the spectrophotometric assay that usually requires derivatization reaction involving ion-pair formation, hydrolysis reaction, time consuming and presenting limited stability. 


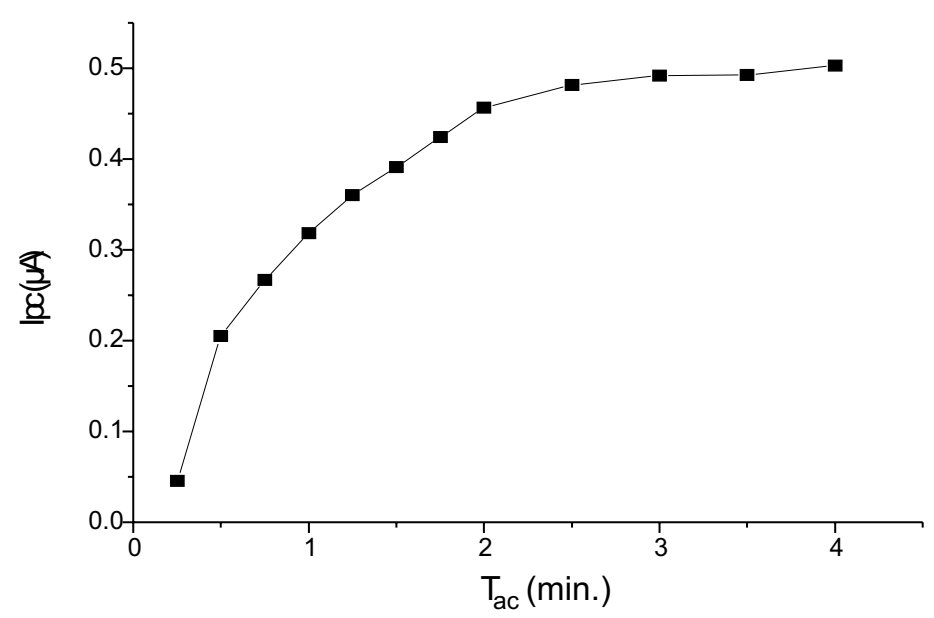

Fig. 4 - Influence of accumulation time on peak current intensity for $1 \times 10^{-6}$ mol L ${ }^{-1}$ of miconazole in B-R buffer $\mathrm{pH} 8.0 . \mathrm{E}_{\mathrm{ac}}=0 \mathrm{~V}$ and $v=100 \mathrm{mV} \mathrm{s}^{-1}$.

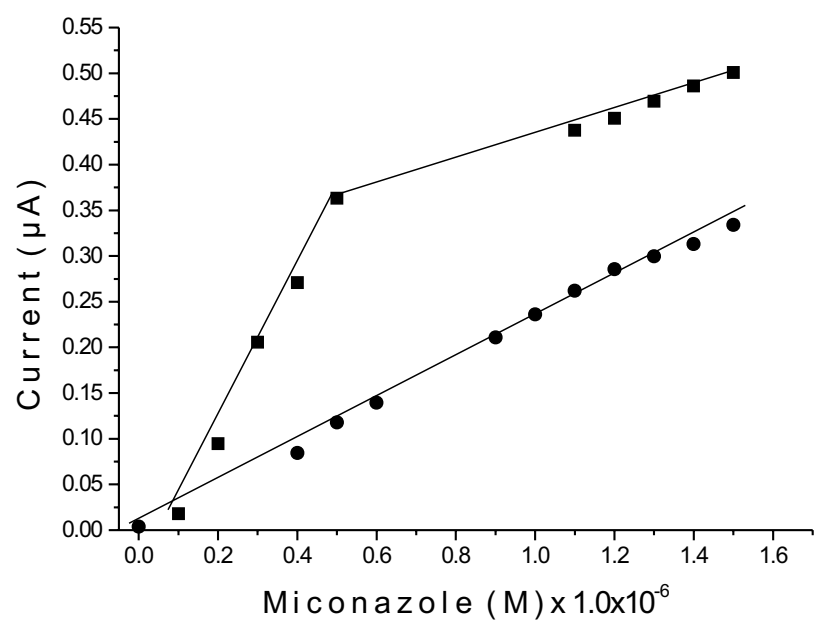

Fig. 5 - Calibration curves obtained for miconazole in B-R buffer $\mathrm{pH}$ 8.0. $\mathrm{E}_{\mathrm{ac}}=0 \mathrm{~V}$, $v=100 \mathrm{mV} \mathrm{s}^{-1}$, using accumulation time of $30 \mathrm{~s}(\bullet)$ and $100 \mathrm{~s}(\square)$.

\section{ACKNOWLEDGMENTS}

The authors thank the financial support from FAPESP, CAPES and CNPq.

\section{RESUMO}

Miconazol é reduzido no eletrodo de mercúrio em valor de $\mathrm{pH}$ acima de 6,0 envolvendo formação de composto organometálico, responsável por um comportamento polarográfico anômalo. O processo eletródico apresenta uma larga contribuição de efeitos de adsorção. A droga pode ser determinada por voltametria de redissolução catódica de $8,0 \times 10^{-8}$ a $1,5 \times 10^{-6} \mathrm{~mol} \mathrm{~L}^{-1}$ em tampão Britton-Robinson $\mathrm{pH} 8,0$ quando pré-acumulada por $30 \mathrm{~s}$ em potencial de acúmulo de $0 \mathrm{~V}$. Um desvio padrão relativo de $3,8 \%$ foi obtido de 10 medidas de $1,0 \times 10^{-7}$ mol 


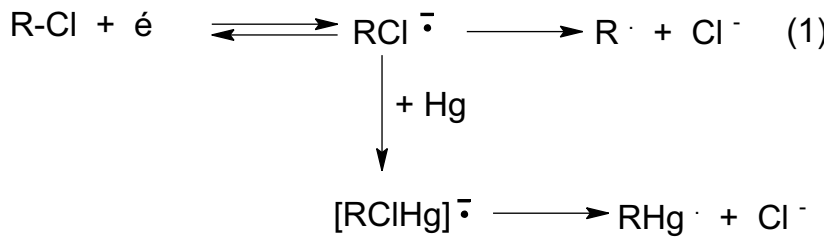

Fig. 6-Reduction scheme of clotrimazole on mercury electrode.

TABLE I

Analysis of miconazole in pharmaceutical formulations by voltammetric method.

\begin{tabular}{l|c|c|c}
\hline Samples & $\begin{array}{c}\text { Label concentration } \\
\left(\mathrm{mol} \mathrm{L}^{-1}\right)\end{array}$ & $\begin{array}{c}\text { Concentration found by } \\
\text { the proposed method } \\
\left(\mathrm{mol} \mathrm{L}^{-1}\right)\end{array}$ & $\begin{array}{c}\text { Comparison } \\
(\%) \pm \mathrm{SD}\end{array}$ \\
\hline Daktarin & $2.0 \times 10^{-7}$ & $2.0 \times 10^{-7}$ & $100 \pm 0.002$ \\
Daktarin & $4.0 \times 10^{-7}$ & $4.0 \times 10^{-7}$ & $100 \pm 0.002$ \\
Daktarin & $1.0 \times 10^{-6}$ & $9.9 \times 10^{-7}$ & $99.1 \pm 0.008$ \\
Vodol & $6.0 \times 10^{-7}$ & $5.9 \times 10^{-7}$ & $98.6 \pm 0.004$ \\
Vodol & $8.0 \times 10^{-7}$ & $7.9 \times 10^{-7}$ & $98.4 \pm 0.002$ \\
Vodol & $1.0 \times 10^{-6}$ & $9.8 \times 10^{-6}$ & $98.1 \pm 0.001$ \\
\hline
\end{tabular}

TABLE II

Analysis of miconazole in pharmaceutical formulations by spectrophotometric method (Cavrini et al. 1981).

\begin{tabular}{l|c|c|c}
\hline Samples & $\begin{array}{c}\text { Label concentration } \\
\left(\mathrm{mol} \mathrm{L}^{-1}\right)\end{array}$ & $\begin{array}{c}\text { Concentration found by } \\
\text { the official method } \\
\left(\mathrm{mol} \mathrm{L}^{-1}\right)\end{array}$ & $\begin{array}{c}\text { Comparison } \\
(\%) \pm \mathrm{SD}\end{array}$ \\
\hline Daktarin & $1.3 \times 10^{-5}$ & $1.3 \times 10^{-5}$ & $100 \pm 0.002$ \\
Vodol & $1.3 \times 10^{-5}$ & $1.2 \times 10^{-5}$ & $99.0 \pm 0.003$ \\
\hline
\end{tabular}

$\mathrm{L}^{-1}$ de miconazol em tampão B-R pH 8,0 e um limite de detecção de $1,7 \times 10^{-8} \mathrm{~mol} \mathrm{~L}^{-1}$ foi determinado usando $60 \mathrm{~s}$ de tempo de deposição e velocidade de varredura de $100 \mathrm{mV} \mathrm{s}^{-1}$. O método proposto é simples, preciso e foi aplicado com sucesso para a determinação de miconazol na forma pura e em formulações comerciais, mostrando médias de recuperação de $99,7-98,4 \%$.

Palavras-chave: miconazol, voltametria, eletroanálise, determinação.

\section{REFERENCES}

BAIZer MM AND Lund H. 1985. Organic electrochemistry. Marcel Dekker, New York: 1985, 259-270 p.

BenNetT JE. 1996. Fármacos antimicrobianos. Goodman \& Gilman (Ed), As bases farmacológicas da terapêutica, $9^{\mathrm{a}}$ ed., Rio de Janeiro: Guanabara, 864$875 \mathrm{p}$.

Bonazzi D, Cavrini V and Gatti R. 1998. Determination of imidazole antimycotics in creams by su- 
percritical fluid extraction and derivative UV spectroscopy. J Pharmaceut Biomed Anal 18: 235-240.

Bond AM. 1980. Modern polarographic methods in analytical chemistry, New York: Marcel Dekker, $121 \mathrm{p}$.

Cavrini V, Di Pietra AM and Raggi MA. 1981. Colorimetric Determination of Miconazole-Nitrate in Pharmaceutical Preparations. Pharm Acta Helv 56: 163 165.

Cavrini V, Pietra AM and Raggi MA. 1982. Highpressure liquid chromatographic analysis of imidazole antifungals in commercial dosage forms. Int $\mathrm{J}$ Pharm 10: 119-124.

Erk N AND Altun ML. 2001. Spectrophotometric resolution of metronidazole and imidazole nitrate in ovules using ratio spectra derivative spectrophotometry. J Pharmaceut Biomed Anal 15: 115-122.

GoGer NG AND GoKCEN L. 1999. Quantitative determination of miconazole in creams by second order derivative spectrophotometric. Anal Lett 32: 2595 2602.

HoogeheIDE JJG AND WyCKa BE. 1982. Analytical profiles of drugs substances, v. 2, New York: Academic Press, 225-255 p.

IndRAyanto G, Widjaja S ANd Sutiono S. 1999. Simultaneous determination of betamethasone valerate and miconazole nitrate in cream, and its validation. J Liquid Chromat 22: 143-152.
Kashaba PY, EL-Shabouri SR and Emara KM. 2000. Analysis of some antifungal drugs by spectrophotometric and spectrofluorimetric methods in different pharmaceutical dosage forms. J Pharmaceut Biomed Anal 22: 363-376.

Kobylinka M, Kobylinka K And SobiK B. 1996. High Performance Liquid Chromatographic Analysis for the determination of miconazole in human plasma using solid-phase extraction. J Chromat B Biomed Sci Appli 685: 191-195.

LAVIRON E. 1974. Adsorption, autoinhibition and autocatalysis in polarographic and in linear potential sweep voltammetry. J Electroanal Chem 52: 35-39.

Pereira FC, Stradiotto NR and Zanoni MVB. 2001. Electrochemical Redution and Cathodic Stripping Voltammetric Determination of Clotrimazole. J Braz Chem Soc 12: 202-207.

Pietra AM, Andrisano V, Gatti R and Cavrini V. 1992. HPLC analysis of imidazole antimicotic drugs in pharmaceutical formulations. J Pharm Biomed Anal 10: 873-879.

Pietra AM, Andrisano V, Gatti R and Cavrini V. 1996. J Pharm Biomed Anal 14: 1191-1199.

Smyth MR and Vos JG. 1992. Analytical voltammetry, vol. XXVII, Amsterdam: Elsevier, 250 p.

Willems GJ, Jottier WI and Ranter CJ. 1981. Polarographic investigation of $\mathrm{Mn}, \mathrm{Fe}, \mathrm{Co}, \mathrm{Ni}$ and $\mathrm{Zn}$ with miconazole. Analysis 9: 327-332.

ZUMAN P. 1969. Elucidation of organic electrode process. New York: Academic Press: p. 16-75. 